\title{
Easing dementia caregiver burden, addressing interpersonal violence
}

\section{Caring for aggressive patients with dementia can lead to exhaustion, fear, and burnout. These strategies can help improve the welfare of both caregivers and patients.}

\section{PRACTICE \\ RECOMMENDATIONS \\ $>$ Screen caregivers and family members of patients with dementia for signs of interpersonal violence. (C)}

> Counsel caregivers early on that behavior changes in patients with dementia are likely and may be unpredictable. (C)

> Discuss safety strategies for the caregiver, including when it is appropriate to alter routines such as bedtimes and meals. (c)

Strength of recommendation (SOR)

A Good-quality patient-oriented evidence

B Inconsistent or limited-quality patient-oriented evidence

C Consensus, usual practice, opinion, disease-oriented evidence, case series
7 he number of people with dementia globally is expected to reach 74.7 million by 2030 and 131.5 million by 2050. ${ }^{1}$ Because dementia is progressive, many patients will exhibit severe symptoms termed behavioral crises. Deteriorating interpersonal conduct and escalating antisocial acts result in an acquired sociopathy. ${ }^{2}$ Increasing cognitive impairment causes these patients to misunderstand intimate care and perceive it as a threat, often resulting in outbursts of violence against their caregivers. ${ }^{3}$

Available studies (TABLE ${ }^{4-17}$ ) make evident the incidence of interpersonal violence experienced by caregivers secondary to aggressive acts by patients with dementia. This violence ranges from verbal abuse, including racial slurs, to physical abusesometimes resulting in significant physical injury. Aggressive behavior by patients with dementia, resulting in violence towards their caregivers or partners, stems from progressive cognitive decline, which can make optimal care difficult. Such episodes may also impair the psychological and physical wellbeing of caregivers, increasing their risk of depression, anxiety, and even post-traumatic stress disorder (PTSD). ${ }^{18}$ The extent of the impact is also determined by the interpretation of the abuse by the caregivers themselves. One study suggested that the perception of aggressive or violent behavior as "normal" by a caregiver reduced the overall negative effect of the interactions. ${ }^{7}$

Our review emphasizes the unintended burden that can fall to caregivers of patients with dementia. We also address the role of primary care providers (PCPs) in identifying these instances of violence and intervening appropriately by providing safety strategies, education, resources, and support.

\section{CASE}

A 67-year-old man with a medical history of PTSD with depression, type 2 diabetes, alcohol use disorder/dependence, hy-

\section{Abu Baker Sheikh, MD; Nismat Javed, MBBS; Zainab ljaz, MD; Katarina Leyba, MD; Eileen Barrett, MD; Angela Dunn, DO University of New Mexico Health Sciences Center, Albuquerque (Drs. Sheikh, Leyba, and Dunn); Shifa College of Medicine, Islamabad, Pakistan (Dr. Javed); William Beaumont Hospital, Royal Oak, MI (Dr. ljaz); University of New Mexico Hospital, Albuquerque (Dr. Barrett); Veterans Affairs Clinics, Albuquerque (Dr. Dunn)}

Dabsheikh@salud.unm.edu

The authors reported no potential conflict of interest relevant to this article.

doi: $10.12788 / \mathrm{ffp} .0349$ 


\section{$>$ \\ Caregivers may refuse support due to personal beliefs or values, accessibility or affordability issues, or in deference to the patient's wishes.}

pertension, and obstructive sleep apnea was brought to his PCP by his wife. She said he had recently been unable to keep appointment times, pay bills, or take his usual medications, venlafaxine and bupropion. She also said his PTSD symptoms had worsened. He was sleeping 12 to 14 hours per day and was increasingly irritable. The patient denied any concerns or changes in his behavior.

The PCP administered a Saint Louis University Mental Status (SLUMS) examination to screen for cognitive impairment. ${ }^{19}$ The patient scored 14/30 (less than 20 is indicative of dementia). He was unable to complete a simple math problem, recall any items from a list of 5 , count in reverse, draw a clock correctly, or recall a full story. Throughout the exam, the patient demonstrated minimal effort and was often only able to complete a task after further prompting by the examiner.

A computed tomography scan of the head revealed no signs of hemorrhage or damage. Thyroid-stimulating hormone levels and vitamin B12 levels were normal. A rapid plasma reagin test result was negative. The patient was given a diagnosis of Alzheimer disease. Donepezil was added to the patient's medications, starting at $5 \mathrm{mg}$ and then increased to $10 \mathrm{mg}$. His wife began to assist him with his tasks of daily living. His mood improved, and his wife noted he began to remember his appointments and take his medications with assistance.

However, the patient's irritability continued to escalate. He grew paranoid and accused his wife of mismanaging their money. This pattern steadily worsened over the course of 6 months. The situation escalated until one day the patient's wife called a mental health hotline reporting that her husband was holding her hostage and threatening to kill her with a gun. He told her, "I can do something to you, and they won't even find a fingernail. It doesn't have to be with a gun either." She was counseled to try to stay calm to avoid aggravating the situation and to go to a safe place and stay there until help arrived.

His memory had worsened to the point that he could not recall any events from the previous 2 years. He was paranoid about anyone entering his home and would not allow his deteriorating roof to be repaired or his yard to be maintained. He did not shower for weeks at a time. He slept holding a rifle and accused his wife of embezzlement.

The patient was evaluated by another specialist, who assessed his SLUMS score to be 18/30. He increased the patient's donepezil dose, initiated a bupropion taper, and added sertraline to the regimen. The PCP spoke to the patient's wife regarding options for her safety including leaving the home, hiding firearms, and calling the police in cases of interpersonal violence. The wife said she did not want to pursue these options. She expressed worry that he might be harmed if he was uncooperative with the police and said there was no one except her to take care of him.

\section{Caregivers struggle to care for their loved ones}

Instances of personal violence lead to shock, astonishment, heartbreak, and fear. Anticipation of a recurrence of violence causes many partners and caregivers to feel exhausted, because there is minimal hope for any chance of improvement. There are a few exceptions, however, as our case will show. In addition to emotional exhaustion, there is also a neverending sense of self-doubt, leading many caregivers to question their ability to handle their family member. ${ }^{20,21}$ Over time, this leads to caregiver burnout, leaving them unable to understand their family member's aggression. The sudden loss of caregiver control in dealing with the patient may also result in the family member exhibiting behavioral changes reflecting emotional trauma. For caregivers who do not live with the patient, they may choose to make fewer or shorter visits-or not visit at all-because they fear being abused. ${ }^{7,22}$

Caregivers of patients with dementia often feel helpless and powerless once abrupt and drastic changes in personality lead to some form of interpersonal violence. Additionally, caregivers with a poor health status are more likely to have lower physical function and experience greater caregiving stress overall. ${ }^{23}$ Other factors increasing stress are longer years of caregiving and the severity of a patient's dementia and functional impairment. $^{23}$ 


\section{Dementia and aggression: A look at the literature}

We conducted searches on PubMed, CINAHL, and EMBASE using the terms "dementia," "aggression," "violence," "caregivers," "agitation," and "behavioural problems." In all, we found 399 studies from 1990 to 2021 . We excluded systematic reviews and meta-analyses as well as non-English language studies. The 14 studies summarized here focused on patients with dementia and their caregivers' experiences with any form of violence or aggression. All included studies examined the experiences of either formal caregivers (eg, nurses, home health aides, paid family caregivers, and nursing home staff) or informal caregivers, such as family members. ${ }^{4-17}$

\begin{tabular}{|c|c|c|}
\hline Author/study type & Aim/criteria & Findings \\
\hline $\begin{array}{l}\text { Skovdahl et al }{ }^{4} \\
\text { Descriptive study }\end{array}$ & $\begin{array}{l}\text { To study caregivers' reflections about, and attitudes } \\
\text { toward, behavioral and psychiatric symptoms of } \\
\text { dementia } \\
\text { Inclusion: Narrative interviews were carried out with } \\
15 \text { formal caregivers who had been permanently } \\
\text { employed for at least } 1 \text { year and who had experienced } \\
\text { aggressive behavior from } 3 \text { different units }\end{array}$ & $\begin{array}{l}\text { Caregivers could not relate to the aggression } \\
\text { of the patients and were having difficulties } \\
\text { administering care owing to verbal violence } \\
\text { experienced daily. }\end{array}$ \\
\hline $\begin{array}{l}\text { Kristiansen et al } \\
\text { Descriptive study }\end{array}$ & $\begin{array}{l}\text { To describe the experience of job satisfaction among } \\
\text { nursing staff working for people with dementia and } \\
\text { behavioral disturbances } \\
\text { Inclusion: All care staff were asked to participate. } \\
\text { Participants included } 19 \text { women and } 1 \text { man. }\end{array}$ & $\begin{array}{l}\text { Most caregivers experienced physical abuse } \\
\text { at work. One person had evidence of physical } \\
\text { injury. }\end{array}$ \\
\hline $\begin{array}{l}\text { Wharton et al } \\
\text { Descriptive study }\end{array}$ & $\begin{array}{l}\text { To review home-based dementia caregiving and care- } \\
\text { recipient violence } \\
\text { Inclusion: NA }\end{array}$ & $\begin{array}{l}\text { Home health care workers were } 4 \text { times } \\
\text { more likely to experience assault if they had } \\
\geq 1 \text { patients with dementia }\end{array}$ \\
\hline $\begin{array}{l}\text { Ostaszkiewicz et al } \\
\text { Descriptive study }\end{array}$ & $\begin{array}{l}\text { To describe nurses' experiences of caring for people } \\
\text { with dementia } \\
\text { Inclusion: All nurses experienced in caring for residents } \\
\text { with dementia and employed on } 3 \text { units }\end{array}$ & $\begin{array}{l}\text { There was evidence of many incidences } \\
\text { of physical abuse and verbal abuse-particularly } \\
\text { racial slurs. }\end{array}$ \\
\hline $\begin{array}{l}\text { Kim et al } \\
\text { Descriptive study }\end{array}$ & $\begin{array}{l}\text { To explore the experience of paid family-care workers } \\
\text { managing the care of people with dementia in } \\
\text { South Korea. } \\
\text { Inclusion: Paid family-care workers who had been } \\
\text { caring for a relative with dementia for at least } 1 \text { month } \\
\text { were recruited to the study. Workers were required } \\
\text { to have had formal education that included clinical } \\
\text { placements and to possess the care worker's license. }\end{array}$ & $\begin{array}{l}\text { Paid family-care workers struggled to manage } \\
\text { the behavioral and psychological symptoms } \\
\text { of their care recipients. } \\
\text { Workloads created physical, emotional, social, } \\
\text { and financial burdens. }\end{array}$ \\
\hline $\begin{array}{l}\text { Band-Winterstein } \\
\text { et } \text { al }^{9} \\
\text { Descriptive study }\end{array}$ & $\begin{array}{l}\text { To differentiate between the experiences of } 2 \text { groups } \\
\text { of women caring for a partner with dementia. They } \\
\text { were coping with lifelong intimate partner violence and } \\
\text { dementia-related violence or dementia-related violence } \\
\text { only. } \\
\text { Inclusion: } 16 \text { participants, all of whom were female } \\
\text { spouses of men with dementia and coping with } \\
\text { dementia-related aggression. }\end{array}$ & $\begin{array}{l}\text { All } 16 \text { women had experienced some sort } \\
\text { of violence. } \\
\text { Participants encountering violence for the first } \\
\text { time viewed it as a drastic abruption. } \\
\text { Recalling positive memories provided caregivers } \\
\text { with strength. } \\
\text { Women reported exhaustion and fatigue } \\
\text { from the episodes of violence. } \\
\text { Two of the } 16 \text { participants considered admitting } \\
\text { their partners to an institution because of the } \\
\text { violence they faced. }\end{array}$ \\
\hline
\end{tabular}

Interventions to reduce caregiver burden

Many studies have assessed the role of different interventions to reduce caregiver bur- den, such as teaching them problem-solving skills, increasing their knowledge of dementia, recommending social resources, providing emotional support, changing caregiver 
TABLE

\section{Dementia and aggression: A look at the literature (cont'd)}

\begin{tabular}{|c|c|c|}
\hline Author/study type & Aim/criteria & Findings \\
\hline $\begin{array}{l}\text { Munkejord et al }{ }^{10} \\
\text { Descriptive study }\end{array}$ & $\begin{array}{l}\text { To examine the experiences of older women in Nordic } \\
\text { culture caring for a spouse with cognitive decline. } \\
\text { Inclusion: } 11 \text { older women, residents of Iceland or } \\
\text { Norway, caring for a spouse with cognitive decline. }\end{array}$ & $\begin{array}{l}\text { State of shock at the onset of symptoms. } \\
\text { Sense of confinement. } \\
\text { Hiding of household items (eg, knives) } \\
\text { for safety. } \\
\text { Development of exhaustion, psychosis, } \\
\text { and "broken heart syndrome." }\end{array}$ \\
\hline $\begin{array}{l}\text { Seidel et al }{ }^{11} \\
\text { Descriptive study }\end{array}$ & $\begin{array}{l}\text { To describe family caregivers' and professional } \\
\text { caregivers' burden after hospitalization of patients with } \\
\text { dementia. } \\
\text { Inclusion: Family members who were the patient's } \\
\text { main caregiver; and professional caregivers with major } \\
\text { involvement in care of the person with dementia. }\end{array}$ & $\begin{array}{l}\text { Highest burden in caregivers was due } \\
\text { to perceived conflicts between their own needs } \\
\text { and their responsibilities. } \\
\text { Family caregivers perceived a higher burden } \\
\text { than did professional caregivers. } \\
\text { The burden due to aggressive and disoriented } \\
\text { behavior, personal constraints, and social } \\
\text { appreciation was more likely perceived } \\
\text { by daughters-in-law. } \\
\text { The burden due to care tasks was more likely } \\
\text { perceived by spouses and life partners. } \\
\text { Compared with professionals, family caregivers } \\
\text { perceived a higher burden from the patient's } \\
\text { cognitive impairment and aggressive } \\
\text { and disoriented behavior. }\end{array}$ \\
\hline $\begin{array}{l}\text { Tang et al }{ }^{12} \\
\text { Survey }\end{array}$ & $\begin{array}{l}\text { To describe experiences of caregivers of people } \\
\text { with Alzheimer disease and related dementias } \\
\text { on self-reported health, type of assistance provided, } \\
\text { perceptions of how caregiving interferes with their } \\
\text { lives, and perceived level of support. } \\
\text { Inclusion: A sub-sample of adults who self-identified as } \\
\text { providing regular care or assistance to a friend or family } \\
\text { member with a chronic health condition or disability. }\end{array}$ & $\begin{array}{l}4.8 \% \text { of the participants reported poor health } \\
\text { status. } \\
\text { Important health problems for caregivers } \\
\text { included blood pressure }(35.7 \%) \text {, depression } \\
(18.7 \%) \text {, chronic pain }(16.9 \%) \text {, anxiety }(15.2 \%) \text {, } \\
\text { and insomnia/sleep disorder }(14.3 \%) \text {. }\end{array}$ \\
\hline $\begin{array}{l}\text { Benbow et al }{ }^{13} \\
\text { Descriptive study }\end{array}$ & $\begin{array}{l}\text { To report instances of violence and to contribute } \\
\text { to prevention of these instances. } \\
\text { Inclusion: Reviews of the following cases were included: } \\
\text { 1. Victim only, age }>60 \mathrm{y} \\
\text { 2. Perpetrator/alleged perpetrator only, age }>60 \mathrm{y} \\
\text { 3. Victim and perpetrator, age }>60 \mathrm{y} \text {. }\end{array}$ & $\begin{array}{l}\text { In } 7 / 30 \text { cases, underlying mental illness of the } \\
\text { perpetrator was determined to be a significant } \\
\text { factor for violence. } \\
\text { In } 11 / 30 \text { reviews, the victim was the } \\
\text { perpetrator's caregiver. }\end{array}$ \\
\hline $\begin{array}{l}\text { Herron et al }{ }^{14} \\
\text { Descriptive study }\end{array}$ & $\begin{array}{l}\text { To determine how agitative or aggressive behaviors } \\
\text { are perceived by the caregivers and to what extent } \\
\text { social or environmental factors have a role. } \\
\text { Inclusion: Purposive sample of caregivers was recruited } \\
\text { for interviews between June } 2016 \text { and June } 2017 \text { in a } \\
\text { largely rural region in southwestern Manitoba, Canada. }\end{array}$ & $\begin{array}{l}\text { Verbal abuse was commonly experienced by } \\
\text { most caregivers. } \\
\text { Formal caregivers reported that scratching and } \\
\text { pinching were common, probably as a result of } \\
\text { their pulling away too quickly during personal } \\
\text { care. } \\
\text { Young male patients were more likely to exhibit } \\
\text { forceful agitative behavior and had to be dealt } \\
\text { with carefully. } \\
\text { Caregivers also identified a lack of mental and } \\
\text { emotional support services for themselves, } \\
\text { which gradually changed their perception of the } \\
\text { patients' actions. }\end{array}$ \\
\hline
\end{tabular}


TABLE

\section{Dementia and aggression: A look at the literature (cont'd)}

\begin{tabular}{|c|c|c|}
\hline Author/study type & Aim/criteria & Findings \\
\hline $\begin{array}{l}\text { Herron et al }{ }^{15} \\
\text { Descriptive study }\end{array}$ & $\begin{array}{l}\text { To report partners' response, interpretation, } \\
\text { and explanation of the aggressive behaviors of patients } \\
\text { with dementia. } \\
\text { Inclusion: Interviews were conducted with people } \\
\text { who identified as having formerly (in the past } 1-5 \text { years) } \\
\text { been a partner caring for someone with dementia. }\end{array}$ & $\begin{array}{l}\text { Caregivers understood the triggers of violent } \\
\text { behavior and developed coping mechanisms. } \\
\text { Some caregivers gave patients time and space } \\
\text { until the initial trigger had passed. } \\
\text { Having a formal caregiver at home } \\
\text { in the presence of a family caregiver created } \\
\text { confusion; some caregivers resorted } \\
\text { to managing the patient on their own. } \\
\text { Caregivers felt there was limited support } \\
\text { and time provided by hospital staff, } \\
\text { which was likely due to staff's inadequate } \\
\text { training in managing patients with dementia. }\end{array}$ \\
\hline $\begin{array}{l}\text { Spencer et al }{ }^{16} \\
\text { Descriptive study }\end{array}$ & $\begin{array}{l}\text { To illustrate the defensive strategies used by } \\
\text { the caregivers in the face of violence and to evaluate } \\
\text { these strategies as potential causes for long-term } \\
\text { harmful behaviors. } \\
\text { Inclusion: Pre-diary interviews of caregivers from a large } \\
\text { Canadian city. }\end{array}$ & $\begin{array}{l}\text { Common strategies included flight (leaving } \\
\text { the relationship) and resistance (hospitalizing } \\
\text { or institutionalizing the family member). } \\
\text { Caregivers also tried ways to contain the threat. } \\
\text { One caregiver divorced her husband but did not } \\
\text { report him for stalking her; this was one way } \\
\text { of acting as if the caregiver was still responsible } \\
\text { for the patient. } \\
\text { Because of previous experiences with former } \\
\text { spouses, a caregiver chose not to leave } \\
\text { the relationship and bore the patient's } \\
\text { controlling tendencies. } \\
\text { One caregiver acted indifferently to the entire } \\
\text { situation, as if she were trying to save her } \\
\text { emotional energy. }\end{array}$ \\
\hline $\begin{array}{l}\text { Skovdahl et al }{ }^{17} \\
\text { Descriptive study }\end{array}$ & $\begin{array}{l}\text { To obtain insight into the reasoning of the caregivers } \\
\text { who had reported problems when dealing with older } \\
\text { people with dementia and aggressiveness. } \\
\text { Inclusion: } 9 \text { caregivers from } 2 \text { different nursing homes } \\
\text { participated in the video recording. }\end{array}$ & $\begin{array}{l}\text { Caregivers expressed feelings of vulnerability. } \\
\text { Routines gave the caregivers a sense of control } \\
\text { and structure. }\end{array}$ \\
\hline
\end{tabular}

NA, not available.

perceptions of the care situation, introducing coping strategies, relying on strengths and experiences in caregiving, help-seeking, and engaging in activity programs. ${ }^{24-28}$ For Hispanic caregivers, a structured and selfpaced online telenovela format has been effective in improving care and relieving caregiver stress. ${ }^{29}$ Online positive emotion regulators helped in significantly improving quality of life and physical health in the caregivers. ${ }^{30}$ In this last intervention, caregivers had 6 online sessions with a facilitator who taught them emotional regulation skills that included: noticing positive events, capitalizing on them, and feeling gratitude; practicing mindfulness; doing a positive reappraisal; acknowledging personal strengths and setting attainable goals; and performing acts of kindness. Empowerment programs have also shown significant improvement in the wellbeing of caregivers. ${ }^{31}$

- Caregivers may reject support. Hindrances to caregivers accepting support can include personal factors (eg, attitude, beliefs, values), service-related issues (eg, accessibility, affordability), and relational factors (preferences of the patient). ${ }^{32}$ In the case of patients with dementia who had a higher functional status, caregivers tend to reject any form of support. ${ }^{32}$ PCPs, of course, are 
optimally suited to care for entire families, often having known their patients and family members for years.

\section{These practical tips can help}

Based on our review of the literature, we recommend offering the following supports to caregivers:

- Counsel caregivers early on in a patient's dementia that behavior changes are likely and may be unpredictable. Explain that dementia can involve changes to personality and behavior as well as memory difficulties. ${ }^{33,34}$

- Describe resources for support, such as day programs for senior adults, insurance coverage for caregiver respite programs, and the Alzheimer's Association (www.alz.org/). Encourage caregivers to seek general medical and mental health care for themselves. Caregivers should have opportunities and support to discuss their experiences and to be appropriately trained for the challenge of caring for a family member with dementia. ${ }^{35}$

- Encourage disclosure about abrupt changes in the patient's behavior. This invites families to discuss issues with you and may make them more comfortable with such conversations.

- Involve ancillary services (eg, social worker) to plan for a higher level of care well in advance of it becoming necessary.

- Discuss safety strategies for the caregiver, including when it is appropriate to alter a patient's set routines such as bedtimes and mealtimes. ${ }^{33,34}$

- Discuss when and how to involve law enforcement, if necessary. ${ }^{33,34}$ Emphasize the importance of removing firearms from the home as a safety measure. Although federal laws do not explicitly prohibit possession of arms by patients with neurologic damage, a few states mention "organic brain syndrome" or "dementia" as conditions prohibiting use or possession of firearms. ${ }^{36}$

- Suggest, as feasible, nonpharmacologic aids for the patient such as mas- sage therapy, animal-assisted therapy, personalized interventions, music therapy, and light therapy. ${ }^{37}$ Prescribe medications to the patient to aid in behavior modification when appropriate.

- Screen caregivers and family members for signs of interpersonal violence. Take notice of changes in caregiver behavior or irregularity in attending follow-up appointments.

\section{CASE}

Over the next month, the patient's symptoms further deteriorated. His PCP recommended hospitalization, but the patient and his wife declined. Magnetic resonance imaging of the patient's brain revealed severe confluent and patchy regions of white matter and $\mathrm{T} 2$ signal hyperintensity, consistent with chronic microvascular ischemic disease. An old, small, left parietal lobe infarct was also noted.

One month later, the patient presented to the emergency department. His symptoms were largely unchanged, but his wife indicated that she could no longer live at home due to burnout. The patient's medications were adjusted, but he was not admitted for inpatient care. His wife said they needed help at home, but the patient opposed the idea any time that it was mentioned.

A few weeks later, the patient presented for outpatient follow-up. He was delusional, believing that the government was compelling citizens to take sertraline in order to harm their mental health. He had also begun viewing online pornography in front of his wife and attempting to remove all of his money from the bank. He was prescribed aripiprazole $15 \mathrm{mg}$, and his symptoms began to improve. Soon after, however, he threatened to kill his grandson, then took all his Lasix pills (a 7-day supply) simultaneously. The patient denied that this was a suicide attempt.

Over the course of the next month, the patient began to report hearing voices. A neuropsychological evaluation confirmed a diagnosis of dementia with psychiatric symptoms due to neurologic injury. The patient was referred to a geriatric psychiatrist and continued to be managed medically. He was assigned a multidisciplinary team comprising palliative care, social work, and care manage- 
ment to assist in his care and provide support to the family. His behavior improved.

At the time of this publication, the patient's irritability and paranoia had subsided and he had made no further threats to his family. He has allowed a home health aide into the house and has agreed to have his roof repaired. His wife still lives with him and assists him with activities of daily living.

\section{Interprofessional teams are key}

Caregiver burnout increases the risk of patient neglect or abuse, as individuals who have been the targets of aggressive behavior are more likely to leave demented patients unattended. ${ }^{8,16,23}$ Although tools are available to screen caregivers for depression and burnout, an important step forward would be to develop an interprofessional team to aid in identifying and closely following high-risk patient-caregiver groups. This continual and varied assessment of psychosocial stressors could help prevent the development of violent interactions. These teams would allow integration with the primary health care system by frequent and effective shared communication of knowledge, development of goals, and shared decision-making. ${ }^{38}$ Setting expectations, providing support, and discussing safety strategies can improve the health and welfare of caregivers and patients with dementia alike.

\section{CORRESPONDENCE}

Abu Baker Sheikh, MD, MSC 10-5550, 1 University of New Mexico, Albuquerque, NM 87131; absheikh@salud.unm.edu.

\section{References}

1. Wu YT, Beiser AS, Breteler MMB, et al. The changing prevalence and incidence of dementia over time - current evidence. Nat Rev Neurol. 2017;13:327-339.

2. Cipriani G, Borin G, Vedovello M, et al. Sociopathic behavior and dementia. Acta Neurol Belg. 2013;113:111-115.

3. Cipriani G, Lucetti C, Danti S, et al. Violent and criminal manifestations in dementia patients. Geriatr Gerontol Int. 2016;16: 541-549.

4. Skovdahl K, Kihlgren AL, Kihlgren M. Different attitudes when handling aggressive behaviour in dementia-narratives from two caregiver groups. Aging Ment Health. 2003;7:277-286.

5. Kristiansen L, Hellzén O, Asplund K. Swedish assistant nurses' experiences of job satisfaction when caring for persons suffering from dementia and behavioural disturbances. An interview study. Int J Qualitat Stud Health Well-being. 2006;1:245-256.

6. Wharton TC, Ford BK. What is known about dementia care recipient violence and aggression against caregivers? J Gerontol Soc Work. 2014;57:460-477.

7. Ostaszkiewicz J, Lakhan P, O'Connell B, et al. Ongoing challenges responding to behavioural and psychological symptoms of dementia. Int Nurs Rev. 2015;62:506-516.

8. Kim J, De Bellis AM, Xiao LD. The experience of paid family-care workers of people with dementia in South Korea. Asian Nurs Res (Korean Soc Nurs Sci). 2018;12:34-41.

9. Band-Winterstein T, Avieli H. Women coping with a partner's dementia-related violence: a qualitative study. J Nurs Scholarsh. 2019; 51:368-379.

10. Munkejord MC, Stefansdottir OA, Sveinbjarnardottir EK. Who cares for the carer? The suffering, struggles and unmet needs of older women caring for husbands living with cognitive decline. Int Pract Devel J. 2020;10:1-11.

11. Seidel D, Thyrian JR. Burden of caring for people with dementia - comparing family caregivers and professional caregivers. A descriptive study. J Multidiscip Healthc. 2019;12:655-663.

12. Tang W, Friedman DB, Kannaley K, et al. Experiences of caregivers by care recipient's health condition: a study of caregivers for Alzheimer's disease and related dementias versus other chronic conditions. Geriatr Nurs. 2019;40:181-184.

13. Benbow SM, Bhattacharyya S, Kingston P. Older adults and violence: an analysis of domestic homicide reviews in England involving adults over 60 years of age. Ageing Soc. 2018;39: 1097-1121.

14. Herron RV, Wrathall MA. Putting responsive behaviours in place examining how formal and informal carers understand the actions of people with dementia. Soc Sci Med. 2018;204:9-15.

15. Herron RV, Rosenberg MW. Responding to aggression and reactive behaviours in the home. Dementia (London). 2019;18 1328-1340.

16. Spencer D, Funk LM, Herron RV, et al. Fear, defensive strategies and caring for cognitively impaired family members. J Geronto Soc Work. 2019;62:67-85.

17. Skovdahl K, Kihlgren AL, Kihlgren M. Dementia and aggressiveness: stimulated recall interviews with caregivers after videorecorded interactions. J Clin Nurs. 2004;13:515-525.

18. Needham I, Abderhalden C, Halfens RJ, et al. Non-somatic effects of patient aggression on nurses: a systematic review. J Adv Nurs. 2005;49:283-296.

19. Tariq SH, Tumosa N, Chibnall JT, et al. The Saint Louis University Mental Status (SLUMS) Examination for detecting mild cognitive impairment and dementia is more sensitive than the MiniMental Status Examination (MMSE) - a pilot study. Am J Geriatr Psych. 2006;14:900-910.

20. Janzen S, Zecevic AA, Kloseck M, et al. Managing agitation using nonpharmacological interventions for seniors with dementia Am J Alzheimers Dis Other Demen. 2013;28:524-532.

21. Zeller A, Dassen T, Kok G, et al. Nursing home caregivers' explanations for and coping strategies with residents' aggression: a qualitative study. J Clin Nurs. 2011;20:2469-2478.

22. Alzheimer's Society. Fix dementia care: homecare. Accessed December 28, 2021. https://www.alzheimers.org.uk/sites/default/ files/migrate/downloads/fix_dementia_care_homecare_report. pdf

23. von Känel R, Mausbach BT, Dimsdale JE, et al. Refining caregiver vulnerability for clinical practice: determinants of self-rated health in spousal dementia caregivers. BMC Geriatr. 2019;19:18.

24. Chen HM, Huang MF, Yeh YC, et al. Effectiveness of coping strategies intervention on caregiver burden among caregivers of elderly patients with dementia. Psychogeriatrics. 2015; 15:20-25.

25. Wawrziczny E, Larochette C, Papo D, et al. A customized intervention for dementia caregivers: a quasi-experimental design. J Aging Health. 2019;31:1172-1195.

26. Gitlin LN, Piersol CV, Hodgson N, et al. Reducing neuropsychiatric symptoms in persons with dementia and associated burden in family caregivers using tailored activities: Design and methods of a randomized clinical trial. Contemp Clin Trials. 2016;49:92-102.

27. de Oliveira AM, Radanovic M, Homem de Mello PC, et al. An intervention to reduce neuropsychiatric symptoms and caregiver burden in dementia: preliminary results from a randomized trial of the tailored activity program-outpatient version. Int J Geriatr Psychiatry. 2019;34:1301-1307.

28. Livingston G, Barber J, Rapaport P, et al. Clinical effectiveness of a manual based coping strategy programme (START, STrAtegies for RelaTives) in promoting the mental health of carers of family members with dementia: pragmatic randomised controlled trial. BMJ. 2013;347:f6276.

29. Kajiyama B, Fernandez G, Carter EA, et al. Helping Hispanic dementia caregivers cope with stress using technology-based resources. Clin Gerontol. 2018;41:209-216.
An important step forward would be to develop an interprofessional team to aid in identifying and closely following high-risk patientcaregiver groups. 
30. Moskowitz JT, Cheung EO, Snowberg KE, et al Randomized controlled trial of a facilitated online positive emotion regulation intervention for dementia caregivers. Health Psychol. 2019;38: 391-402.

31. Yoon HK, Kim GS. An empowerment program for family caregivers of people with dementia. Public Health Nurs. 2020;37: 222-233.

32. Zwingmann I, Dreier-Wolfgramm A, Esser A, et al. Why do family dementia caregivers reject caregiver support services? Analyzing types of rejection and associated health-impairments in a clusterrandomized controlled intervention trial. BMC Health Serv Res. 2020;20:121.

33. Nybakken S, Strandås M, Bondas T. Caregivers' perceptions of aggressive behaviour in nursing home residents living with dementia: A meta-ethnography. J Adv Nurs. 2018;74:2713-2726.
34. Nakaishi L, Moss H, Weinstein M, et al. Exploring workplace violence among home care workers in a consumer-driven home health care program. Workplace Health Saf. 2013;61:441-450.

35. Medical Advisory Secretariat. Caregiver- and patient-directed interventions for dementia: an evidence-based analysis. Ont Health Technol Assess Ser. 2008;8:1-98.

36. Betz ME, McCourt AD, Vernick JS, et al. Firearms and dementia: clinical considerations. Ann Intern Med. 2018;169:47-49.

37. Leng M, Zhao Y, Wang Z. Comparative efficacy of non-pharmacological interventions on agitation in people with dementia: a systematic review and Bayesian network meta-analysis. Int J Nurs Stud. 2020;102:103489.

38. Morgan S, Pullon S, McKinlay E. Observation of interprofessional collaborative practice in primary care teams: an integrative literature review. Int J Nurs Stud. 2015;52:1217-1230. 